\title{
Structural, Optical and Electrical Characterizations of Cr-doped CuO Thin Films
}

\author{
Silan BATURAYI Ilhan CANDAN ${ }^{1,2 *}$ Cihat OZAYDIN ${ }^{3}$ \\ ${ }^{1}$ Dicle University, Faculty of Science, Department of Physics, 21280, Diyarbakir, Turkey \\ ${ }^{2}$ Dicle University, Institute of Science and Technology, Department of Physics, 21280, Diyarbakir, Turkey \\ ${ }^{3}$ Department of Computer Engineering, Faculty of Engineering, University of Batman, 72100, Batman, Turkey \\ *Corresponding author: ilhan.candan@ dicle.edu.tr
}

\begin{abstract}
The polycrystalline copper oxide $(\mathrm{CuO})$ thin films have been produced using method of spin coating onto the soda lime glass (SLG) as well as substrate of p-type $\mathrm{Si}\left(\begin{array}{lll}1 & 0 & 0\end{array}\right)$ wafers at $500{ }^{\circ} \mathrm{C}$ in furnace. The obtained undoped and $\mathrm{Cr}$ doped thin films of $\mathrm{CuO}$ have been comprehensively characterized via X-ray diffraction (XRD), ultraviolet-vis (UV-vis) spectroscopy, the current-voltage $(I-V)$ and capacitance-voltage $(C-V)$ characteristics for providing information on quality of the crystalline nature, change in energy band gap and electrical properties, respectively. Structural analysis results which obtained from XRD data demonstrate that $\mathrm{CuO}$ films conjunction with $\mathrm{Cr}$ doping indicated that all thin films have monoclinic polycrystalline nature, with two main peaks (002) and (111) with $\mathrm{d}_{\mathrm{hkl}}$ about 2.52 and $2.32 \AA$, respectively. The transmittance and energy band gap value of undoped and $\mathrm{Cr}$ doped thin films of $\mathrm{CuO}$ ranging in varying concentration ratio have been determined in the wavelength region of 300 to $1100 \mathrm{~nm}$. UV-vis spectrum analysis results indicate that both transmittance value and energy band gap of the $\mathrm{CuO}$ films is changed with increasing $\mathrm{Cr}$ doping ratio in $\mathrm{CuO}$ solution at room temperature. The $\mathrm{I}-\mathrm{V}$ and $\mathrm{C}-\mathrm{V}$ characteristic of $\mathrm{Cr}: \mathrm{CuO} / \mathrm{p}-\mathrm{Si}$ diodes were associated with the $\mathrm{CuO} / \mathrm{p}-\mathrm{Si}$ diodes. It is seen that doping of $\mathrm{Cr}$ had a significant change onv the obtained devices' performance. Thus, the $\mathrm{Cr}: \mathrm{CuO} / \mathrm{p}-\mathrm{Si}$ diodes generated by $1 \%$ $\mathrm{Cr}$ doping using spin coating method had the highest light sensitivity compared with those of the other diodes.
\end{abstract}

Keywords: $\mathrm{Cr}, \mathrm{CuO}$, thin films, spin coating, $\mathrm{Cr}: \mathrm{CuO} / \mathrm{p}$-Si diodes

\section{Introduction}

The metal oxide nanostructures' extraordinary properties and structural difference started wide-ranging research focus in various nanoscale fields including electronics, catalysis, optics, optoelectronics, and biosensors [1-4]. As a metal oxide semiconductor view, $\mathrm{CuO}$ nanofilms are a major interest between other kinds of the metal oxide semiconductor. Copper oxide should be classified in two different stable forms which are known cupric oxide $(\mathrm{CuO})$ and cuprous oxide $\left(\mathrm{Cu}_{2} \mathrm{O}\right)$. $\mathrm{CuO}$ with nanostructures having semiconductor material of p-type conductivity exhibits intriguing properties such as direct energy band gap value (between 1.1 and $2.1 \mathrm{eV}$ ) [5,6], environment friendly and unique chemical stability and in contrast, $\mathrm{Cu}_{2} \mathrm{O}$ has cubic structure that has 2-2.6 eV energy band gap with black color [7]. $\mathrm{CuO}$ as a semiconductor candidate is very promising for various application areas including $\mathrm{H}_{2}$ gas sensors [8], $\mathrm{CO}_{2}$ sensor [9], cross-point memory [10], solar selective absorber [11], solar cell [12], photoelectrochemical applications [13], perovskite solar cells [14] and electrochemical supercapacitors [15] owing to abundant availability in nature and low cost synthesis and easy preparation process of copper production $[16,17]$. It should be noted that, $\mathrm{CuO}$ has been both direct [18] and indirect energy band gap [19] more than cuprous oxide compound and fabrication methods strongly effect these values. Kuhaili indicated that cupric oxide for temperatures only below $300{ }^{\circ} \mathrm{C}$ is the stable phase at different partial pressure of oxygen $\left(\mathrm{P}\left(\mathrm{O}_{2}\right)\right)$, and merely less that $1000{ }^{\circ} \mathrm{C}$ for atmospheric pressure, the equilibrium phase diagram of the Cupper-Oxygen (Cu-O) system [20]. Otherwise, cuprous oxide is thermodynamically stable only in $\mathrm{P}\left(\mathrm{O}_{2}\right)$ range of temperature, and that is obtained by heating of $\mathrm{Cu}$ with $\mathrm{P}\left(\mathrm{O}_{2}\right)$ below 10 mTorr using a $\mathrm{KrF}$ excimer laser $(248 \mathrm{~nm})$ above $650{ }^{\circ} \mathrm{C}$ [21]. Nevertheless, nanocrystalline $\mathrm{Cu}_{2} \mathrm{O}$ phase was addtionally seen by annealing thin films of $\mathrm{Cu}$ in air at temperatures less than 300 ${ }^{\circ} \mathrm{C}[22,23]$. A single monoclinic $\mathrm{CuO}$ phase was also obtained from the films annealed tubular furnace some increment in the healing temperature such as between 350 and $450{ }^{\circ} \mathrm{C}$ in air condition [22]. The research on $\mathrm{CuO}$ thin films has attracted extensive interest because of the fact that the p-type conducting oxide development [20] has significant importance in technology for $\mathrm{p}-\mathrm{n}$ homo-junction based oxide materilas. Moreover, metalsemiconductor (MS) and metal-interlayer-semiconductor (MIS) type Schottky diodes' electrical properties started considerable interest in experimental studies owing to metal and semiconductor interlayer's different optical and electrical properties [24,25]. Since these devices' performance and reliability is particularly based on the interlayer formation, these devices effect parameters of the device including the barrier height, interface-state density, series resistance as well as ideality factor.

Surface morphology, donor density, surface charge, oxygen vacancies' presence and its catalytic effects in $\mathrm{CuO}$ can be significantly enhanced with doping with $\mathrm{Cr}$ [26,27]. Doping of $\mathrm{Cr}$ is preferred for the semiconductor materials owing to fact that the $\mathrm{CuO}$ material's properties can be significantly changed by the doping of $\mathrm{Cr}$ such 
as $\mathrm{NH}_{3}$ sensing, transmittance value, and optical bang gap [28-30]. Various methods have been used to fabricate $\mathrm{CuO}$ and $\mathrm{Cu}_{2} \mathrm{O}$ thin films with dissimilar morphology. Monoclinic $\mathrm{CuO}$ and cubic $\mathrm{Cu}_{2} \mathrm{O}$ thin films could be manufactured via copper's thermal oxidation at 250 and $350{ }^{\circ} \mathrm{C}$ in the air, respectively [31]. Samarasekara et al fabricated thin films of $\mathrm{CuO}$ using sol-gel spin coating tehnique and investigated $\mathrm{Zn}^{2+}$ doped $\mathrm{CuO}$ thin films' electrical properties. They found $\mathrm{Zn}^{2+}$ doped $\mathrm{CuO}$ films indicate electrochemical cell behavior only after illuminating [32]. Guillen and herrero fabricated thin films of $\mathrm{Cu}_{2} \mathrm{O}$ and $\mathrm{CuO}$ via low-temperature oxidation processes and found that there is one level in the energy band gap of $\mathrm{CuO}$ which was attributed to oxygen's monovacancies and two defect levels next to the $\mathrm{Cu}_{2} \mathrm{O}$ conduction band owing to vacancy complexes and monovacancies [31]. Shaban et al. employed spin-coating technique to investigate phase mixed with $\mathrm{Cu}_{2} \mathrm{O} / \mathrm{CuO}$ structural, optical and gas sensing properties and they found that the sensitivity of $6 \% \mathrm{Cr}$ and $3 \% \mathrm{~S}$ doping of $\mathrm{Cu}_{2} \mathrm{O} / \mathrm{CuO}$ thin films significantly improved from 46 to $99.8 \%$ towards flow rate of $\mathrm{Co}_{2}$ increased from 30 to 150 sccm [33]. Pat et al. [2] deposited CuxO thin film with $\mathrm{Cr}$ doping via technique of thermionic vacuum arc plasma and deposited they had high transparency, and dielectric constant [34].

Recently, transition metal oxides have been deposited [35-39] to improve crystalline nature of $\mathrm{CuO}$ thin films. Though different doped $\mathrm{CuO}$ thin films' physical and chemical properties have been examined by groups [16,4043], $\mathrm{CuO}$ thin films with $\mathrm{Cr}$ doping are very limited in literature.

In the present study, $\mathrm{CuO}$ thin films with $\mathrm{Cr}$ doping were obtained through conventional, easy, environmentally friendly and suitable for the various size areas grown differently from among the above-mentioned method. The $\mathrm{CuO}$ thin films' structural, morphological and optical properties fabricated on glass and substrates of p-Si using spin coating technique. The obtained $\mathrm{Cr}$ doped films have been investigated employing XRD and UV-vis spectroscopy to provide data on the crystalline nature's quality and surface morphology change of the obtained films. Additionally, we have investigated the diodes' electrical properties to analyze the concentration effect on diode parameters of $\mathrm{Cr}: \mathrm{CuO} / \mathrm{p}-\mathrm{Si}$ diodes by employing measurements of current-voltage (I-V) and capacitancevoltage $(\mathrm{C}-\mathrm{V})$ in the dark and light $\left(100 \mathrm{~mW} / \mathrm{cm}^{2}\right)$.

\section{Experimental}

$\mathrm{Cr}$ doped $\mathrm{CuO}$ thin films with $\mathrm{Cr} / \mathrm{Cu}$ ratios of $0,1,2$ and $3 \%$ were prepared using spin coating method SLG and wafers of p-type Si $\left(\begin{array}{lll}1 & 0 & 0\end{array}\right)$ as substrate that have $1-10 \Omega$-cm resistivity. Before deposition process, SLG substrates were firstly boiled in 5:1:1 deionized water, ammonia and hydrogen peroxide mix for time of $20 \mathrm{~min}$. at a temperature of $90^{\circ} \mathrm{C}$ and in the solution of 5:1:1 deionized water, hydrogen peroxide and hydrogen chloride with same conditions. Then, these cleaned substrates were cleaned in acetone for 5 min each for two times to obtain clear surface. After this process, cleaned substrates cleaned by distilled water and dried under $\mathrm{N}_{2}$ gas, respectively. Then, the $\mathrm{Si}$ wafers to obtain $\mathrm{Cr}: \mathrm{CuO} / \mathrm{p}$-Si diode were boiled for $5 \mathrm{~min}$ in trichloroethylene, and later, stirred for $5 \mathrm{~min}$ in acetone each for two times and ethanol to obtain free of any organic contamination in ultrasonic bath. The wafers were etched in hydrofluoric acid (HF) solution: distilled water $\left(\mathrm{H}_{2} \mathrm{O}\right)(1: 10)$ two times for $30 \mathrm{~s}$ and then cleaned by distilled water to eliminate the native oxide and any chemical residues before inserting these $\mathrm{Si}$ wafers into the vacuum chamber to obtain $\mathrm{Cr}: \mathrm{CuO} / \mathrm{p}$-Si diode. The rear contacts were made by evaporating an $\mathrm{Al}$ metal of $200 \mathrm{~nm}$ thickness on the Si wafers' unprocessed side, and that was continued by a speedy thermal annealing for $3 \mathrm{~min}$ at $570{ }^{\circ} \mathrm{C}$ under a $\mathrm{N}_{2}$ gas.

A $0.1 \mathrm{M}$ copper (II) acetate $\left(\mathrm{Cu}\left(\mathrm{CH}_{3} \mathrm{COO}\right)_{2} \bullet \mathrm{H}_{2} \mathrm{O}\right)$ in ethanol solution was employed as the preliminary material and a $0.01 \mathrm{M}$ solution of chromium (III) chloride $\left(\mathrm{CrCl}_{3} \cdot 6 \mathrm{H}_{2} \mathrm{O}\right)$ in ethanol was used as the dopant source, respectively. The obtained solutions were firstly deposited on p-Si wafer with (100) orientation by spin coating method at $1500 \mathrm{rpm}$ for $55 \mathrm{~s}$ for 3 layers of deposition. After this, the obtained films were annealed for $1 \mathrm{~h}$ in a furnace at $500{ }^{\circ} \mathrm{C}$ under air. Lastly, front contacts of $\mathrm{Al}$ were vaporized onto the $\mathrm{Cr}$ doped $\mathrm{CuO}$ thin films employing a shadow mask for investigating the heterojunctions' electrical properties. Then, obtained solutions were placed on substrates of SLG using the forementioned technique and conditions for 10 layers of deposition to investigate the $\mathrm{Cr}$ doped $\mathrm{CuO}$ thin films' structural and optical properties. During deposition process, each layer of the films was preheated to $230^{\circ} \mathrm{C}$ on a hot plate for 10 minutes to obtain a homogenous surface.

The undoped and $\mathrm{Cr}$ doped $\mathrm{CuO}$ thin films' structural and phase purity analysis were determined by a Rigaku ultima III diffractometer with wavelength of $0.154 \mathrm{~nm}$ at $40 \mathrm{kV}$, and $30 \mathrm{~mA}$ for $\theta-2 \theta$ range in the steps of $0.02^{\circ}(\theta)$ at room temperature. The conclusion of thin films' transmittance and energy band gap was analyzed by UV-Vis spectrophotometer between $300-1100 \mathrm{~nm}$. I-V relations of all films were inspected by a source meter (Keithley 2400 , Cleveland, USA) both in dark and under illumination with ligh with $100 \mathrm{~mW} / \mathrm{cm}^{2}$ light at room temperature to investigate the change of barrier height and ideality factor. 


\section{Structural properties}

The prepared $\mathrm{Cr}$ doped $\mathrm{CuO}$ thin films' structural analysis was investigated by $\mathrm{X}$-Ray diffraction, which was operated by $\mathrm{Cu} \mathrm{K} \alpha$ radiation source $(\lambda=0.154187 \mathrm{~nm})$ and it produced $40 \mathrm{keV}$ and $30 \mathrm{~mA}$ at room temperature for $2 \theta$ values ranging from $20^{\circ}$ to $80^{\circ}$. The obtained samples' XRD patterns are displayed in Figure 1. The positions of peaks at $2 \theta$ angle that are around $35.6^{\circ}, 38.8^{\circ}, 48.8^{\circ}, 53.5^{\circ}, 68.07^{\circ}$, with $\mathrm{d}_{\mathrm{hkl}}$ around $2.52,2.32,1,86,1,71$ and $(1,38) \AA$ were related to (JCPDS 05-6661 for CuO) (002), (111), (-202), (020) and (113) reflections planes, respectively. According to the XRD data, it is said that the samples' XRD patterns show a CuO single phase's existence with a monoclinic structure [1-3]. There are no signs of oxide phases associated with the impurity phase owing to the formation of the possible compounds containing chromium oxides and $\mathrm{Cu}_{2} \mathrm{O}$.

The diffraction data obtained from XRD including the values of peak orientations, strain ( $(\varepsilon)$, grain sizes (D), dislocation density $(\delta)$, inter-planar spacing (d-spacing), and full width at half maximum (FWHM) for strong peaks are given in the Table 1. The intensities of peaks and FWHM values which employed to determine the grain size slightly change with increasing $\mathrm{Cr}$ concentration. $\mathrm{Cr}$ addition in the samples in air at temperature at $500{ }^{\circ} \mathrm{C}$ change the composition and the crystal structure of the thin film; and also the peak intensities and orientation along (002) and (111) were higher. It is said that $\mathrm{Cu}$ ions' exchange changes the structure of crystal or crystallinity slightly owing to the fact that it is probably related to the $\mathrm{Cr}^{+}$ion's atomic radius $(0.62 \AA)$ being smaller than $\mathrm{Cu}^{2+}$ ions' one $\left(0.73 \mathrm{~A}^{\circ}\right)$. When these results compared with previous studies, it was concluded that the given planes' orientation and intensity for $\mathrm{CuO}$ thin films mostly approve strong crystallinity with monoclinic structure [4]. Das and Alford revealed that that the $\mathrm{Ag}$ doped $\mathrm{CuO}$ thin film had preferential orientation along the line in the (111) [5]. Menazea and Ayman is indicated similar results and they showed that had a preferential orientation in the (200) direction [6]. Obulapathi et al. [44] indicated that similar XRD data. They indicated that the intensity of the peaks changed by the addition $\mathrm{Cr}$ into the $\mathrm{CuO}$ thin films.

$\mathrm{Cr}$ doped $\mathrm{CuO}$ thin film's crystallite size $(D)$ was determined by the angular peak width at width at FWHM of (002) and (111) planes by employing the following expression [45].

$D=\frac{0.94 \lambda}{\beta \cos \theta}$

where $\lambda$ is $1.5418 \AA$ as the XRD wavelength, $\theta$ is the angle of Bragg diffraction and $\beta$ is the angular peak width at FWHM and $D$ is the crystallite size of the film of (002) and (111) planes. Calculation from X-ray diffraction data showed change in the crystallite size as a function of the $\mathrm{Cr}$ concentration. The calculation of $\mathrm{Cr}$ doped $\mathrm{CuO}$ thin films' crystallite size shows a change in $D$ value as a $\mathrm{Cr}$ doping function at a500 ${ }^{\circ} \mathrm{C}$ constant annealling temperature. Durai et al. [46] showed that the the $D$ value of the $\mathrm{Cr}$-doped $\mathrm{CuO}$ changes owing to a rise in absorbed atoms' mobility. $\mathrm{d}$ values of the obtained $\mathrm{CuO}$ film are determined by the Bragg's expression:

$2 d \sin \theta=n \lambda$

where $\mathrm{n}$ is the diffraction order. Calculated $d$ values of undoped and $\mathrm{CuO}$ thin films with $\mathrm{Cr}$ doping for (002) and (111) are around 2.52 and 2.32, respectively. The value of dislocation density $(\delta)$ that shows the defects' amount in samples is calculated using the formula below:

$\delta=\frac{1}{D^{2}}$

The change in the strain of the all films is determined using expression [27]:

$\varepsilon=\frac{\beta}{4 \tan \theta}$

The dislocation density value is changed between $56.87 \times 10^{13}$ and $83.47 \times 10^{13} \mathrm{~m}^{-2}$ for (002) plane and $13.88 \times$ $10^{13}$ and $17.19 \times 10^{13} \mathrm{~m}^{-2}$ for (111) plane owing to the fact that the $\delta$ values are inversely proportional to the $D$ value square. Strain values of the (002) and (111) planes is changed with $\mathrm{Cr}$ dopant content. Therefore, it was said that the main effect of change in $D$ is linked to change in strain. Durai et al. [46] showed $\mathrm{Cr}$ doped $\mathrm{CuO}$ films with as function of concentration change show change in strain value owing to strain relaxation with changed $D$ value.

\section{Optical Properties}

The optical properties including absorbance, transmittance and band gap of undoped and $\mathrm{CuO}$ thin films with $\mathrm{Cr}$ doping via spin coating method were detailed analyzed to examine $\mathrm{Cr}$ doping effect by using UV-visible spectrophotometer data in the range of 300-1100 nm. The absorption coefficient and the undoped and Cr doped 
$\mathrm{CuO}$ thin films' optical transmission spectra for four different doping concentration deposited on SLG substrate are given in figure 3 and 4, respectively. It was found that the $\mathrm{CuO}$ thin films' optical transmittance values increase in visible region as compared to undoped $\mathrm{CuO}$ film and the highest value has been found to be around $33 \%$ related to $3 \% \mathrm{Cr}$ doping in the visible range. This upsurge in the value of optical transmittance is assigned to the crystalline nature of the thin film characteristics because these changes are corresponding to the material properties of the thin films. The rise in the transmittance value of obtained $\mathrm{CuO}$ thin film could be ascribed to the Moss-Burstein (M-B) effect [47]. Thus, it is said that the $\mathrm{CuO}$ thin films' optical properties can be changed by $\mathrm{Cr}$ dopant content in the ultraviolet-visible range $(401-750 \mathrm{~nm})$ of the optical spectrum from $300 \mathrm{~nm}$ to $1100 \mathrm{~nm}$. Thus, it is said that the optical properties including transmittance and absorbance of $\mathrm{CuO}$ thin films can be changed by different $\mathrm{Cr}$ dopant content in the ultraviolet-visible range region. The change in values of absorbance and transmittance indicates that $\mathrm{CuO}$ thin films could be applied to numerous applications including photovoltaic devices [48]. Menazea and Mostafa [49] are revealed that the $\mathrm{CuO}$ thin films' optical transmittance value is improved with $\mathrm{Ag}$ doping using Laser Deposition (PLD) technique. They also said that the enhancing in the transmittance value may be allocated to the structural properties of prepared thin films.

The increase of the value of transmittance corresponds to change of the energy band gap corresponding to valence electrons and conduction electrons. The direct energy band gap values of the all thin films are calculated via the Tauc's expression as stated below [50].

$\alpha h v=A(h v-E g)^{m}$

where hv is the radiation energy, Eg is the band gap of the used materials, A is the material's energy independent constant, $\mathrm{n}$ is constant that based on the transition nature, $\mathrm{m}=1 / 2,2,3 / 2$, or 3 for direct, nondirect allowed transition, forbidden direct or forbidden nondirect transitions, respectively. $\alpha$ is a constant that gives the coefficient of absorption in $\mathrm{cm}^{-1}$ which is also calculated using the equation; $\alpha=4 \pi \mathrm{k} / \lambda$; $\mathrm{k}$ is the absorption index of material and $\lambda$ is the wavelength. Figure 4 indicates the plot of $(\alpha h v)^{2}$ versus incident energy of photon (hv) for undoped and $\mathrm{Cr}$ doped $\mathrm{CuO}$ films. Undoped $\mathrm{CuO}$ thin films' calculated band gap value is $1.60 \mathrm{eV}$, which increases to 2.30 $\mathrm{eV}$ after the doped by $\mathrm{Cr}$ in solution. The $\mathrm{Cr}$ doped $\mathrm{CuO}$ thin films are revealing both high transmittance as well as maximum energy band gap among the obtained thin films. Gülen et al indicated that the value of energy band gap was improved with Mn doping concentration in the thin film using SILAR method [51]. Pat et al. [34] revealed that energy band gap value of the $\mathrm{Cr}$ doped $\mathrm{Cu}_{\mathrm{x}} \mathrm{O}$ thin film was measured to be around $2 \mathrm{eV}$ using thermionic vacuum arc plasma. Sajid et al [52] indicated that the pure $\mathrm{CuO}$ thin films' energy band gap is calculated to be $1.87 \mathrm{eV}$ that is greater than bulk $\mathrm{CuO}(1.2 \mathrm{eV})$ because of confinement effects at quantum nanoscale level. Also they are showed that $\mathrm{CuO}$ thin film's energy band gap value has been increased up to $2.61 \mathrm{eV}$ conjunctions with Cr doping owing to effects of band-filling as well as s-d and p-d exchange interactions. Das and Mitra [53] revealed that increase in energy band gap in doped films were seen up to $6 \%$ doping level owing to increase in carrier density in $\mathrm{Ni}$ doped $\mathrm{CuO}$ films.

It is said that increasing $\mathrm{Cr}$ concentration cause evaporation of oxygen and the obtained films become more $\mathrm{Cu}$ rich owing to the fact that the O-rich samples usually have lower energy band gap value [54,55]. Relatively more $\mathrm{Cu}$-rich thin films after $\mathrm{Cr}$ doping owing to the evaporation of excess oxygen from the film surface will have increase in the value of energy band gap as compared to the undoped $\mathrm{CuO}$ film. It is said that the change in the energy band gap conjunction with $\mathrm{Cr}$ doping might be capable for effect of band-filling. Thus, it is said that $\mathrm{Cr}$ could be used to regulate the $\mathrm{CuO}$ thin films' optical band gap for potential electronic equipment.

\section{The Current-Voltage and Capacitance-Voltage Characteristics of the $\mathrm{Cr}: \mathrm{CuO} / \mathrm{p}-\mathrm{Si}$ Diodes}

To evaluate the fabricated heterojunction diodes' electrical properties, semi-logarithmic I-V plots were drawn from current-voltage measurements in the dark and under light $\left(100 \mathrm{mw} / \mathrm{cm}^{2}\right)$. All diodes' I-V characteristics in the dark are shown in figure 5 .

As seen in figure 5, although the best rectification ratio $(R R)$ is seen in the $1 \% \mathrm{Cr}$ doped diode $\left(\mathrm{RR}=2.33 \times 10^{3}\right.$ for $\pm 1 \mathrm{~V}$ ), other diodes also have significant rectification behavior. At relatively low voltages, the $\mathrm{Cr}: \mathrm{CuO} / \mathrm{p}-\mathrm{Si}$ heterojunction acts like a Schottky barrier diode [56]. Therefore, the $\mathrm{Cr}: \mathrm{CuO} / \mathrm{p}-\mathrm{Si}$ diodes' I-V characteristics are explained by theory of Thermionic Emission (TE) which is well-known and stated in the following equations;

$I=I_{0} \exp \left(\frac{q V}{n k T}\right)\left[1-\exp \left(-\frac{q V}{k t}\right)\right]$ 
Where $V$ is the applied voltage, $n$ is the ideality factor, $k$ is the Boltzmann constant, $\mathrm{T}$ is the absolute temperature in Kelvin, and $I_{0}$ is the saturation current which is given by:

$I_{0}=A A^{*} T^{2} \exp \left(\frac{-q \phi_{b}}{k T}\right)$

Where $A$ is the diode area $\left(7.85 \times 10^{-3} \mathrm{~cm}^{2}\right), A^{*}$ is the effective Richardson constant and equal to $32 \mathrm{Acm}^{-2} \mathrm{~K}^{-2}$ for p-type $\mathrm{Si}, q$ is the electron charge, and $\phi_{b}$ is the barrier height. The ideality factor $n$ is related to the diode's conformity in the TE theory, and it is calculated from the linear region's slope of the forward bias in the plot of $\ln (\mathrm{I})-\mathrm{V}$ characteristics via the folowing relation (for $V \geq 3 k T / q$ ):

$n=\frac{q}{k T}\left(\frac{d V}{d \ln I}\right)$

The diode parameters $n, \phi_{b}, I_{0}$ and $R R$ are determined from the experimental $\mathrm{I}-\mathrm{V}$ data at $300 \mathrm{~K}$ temperature and are given in Table 2 . The results show that $\% 1 \mathrm{Cr}$ doping to $\mathrm{CuO}$ causes a slight improvement in the ideality factor. However, all produced the diodes' ideality factors are higher than unity, indicating that they demonstrate behavior of non-ideal diode. Ideality factors' higher values are associated to secondary mechanisms that involve dipoles of interface because of doped interface or structure of specific interface, and also defects of fabrication at the interface [57]. Furthermore, n's large values may also be related to a wide distribution of low Schottky barrier patches due to the laterally inhomogeneous barrier [58]. Erdoğan and Güllü [57], calculated the ideality factor and barrier height being as 2.39 and $0.64 \mathrm{eV}$, respectively, in the $\mathrm{Au} / \mathrm{CuO} / \mathrm{p}-\mathrm{Si}$ diode they constructed by the simple chemical method. Similarly, Ruzgar et al. [59] reported $\mathrm{Au} /(\mathrm{CuO}: \mathrm{La}) / \mathrm{n}-\mathrm{Si}$ photodiode's electrical performance that is formed with undoped $\mathrm{CuO}$ and $\mathrm{La}$-doped $\mathrm{CuO}$ thin films produced by spin coating method. They calculated the best ideality value as 2.04 with $2 \%$ La doping $\mathrm{CuO}$.

Another important parameter for Schottky barrier diodes is the barrier height $\left(\phi_{b}\right)$. Akin to the improving the diodes' ideality factor values, the height of barrier becomes optimum and maximum value reaching to $0.81 \mathrm{eV}$ with $1 \% \mathrm{Cr}$ doping. The $0.81 \mathrm{eV} \phi_{b}$ value we attained for the $\mathrm{Al} / \% 2 \mathrm{Cr}: \mathrm{CuO} / \mathrm{p}-\mathrm{Si}$ device is considerably higher than both the barrier heights of the other diodes here and the conventional MS contacts diode's value such as the $\mathrm{Al} / \mathrm{p}$-Si diode, where $\phi_{b}$ is approximately $0.70 \mathrm{eV}$ [60]. Some research have experimentally been carried out for the modification of barrier employing the thin films' interlayer [59]. Recently, Ruzgar et al. [8] have published a paper about the $\mathrm{Au} / \mathrm{Fe}: \mathrm{CuO} / \mathrm{n}$-si diode made by doping $\mathrm{Fe}$ to $\mathrm{CuO}$. They reported that the barrier height changed with Fe doping to $\mathrm{CuO}$ and that the barrier height decreased as Fe doping increased. Similarly, Singh et al. [61] obtained 2.8 ideality factor and $0.82 \mathrm{eV}$ barrier height for the $\mathrm{n}-\mathrm{CuO} / \mathrm{p}-\mathrm{Si}$ diode, which they formed by method of sol-gel spin coating. In another study, Ruzgar et al. [59] stated that the height of barrier was the highest and optimum when the La contribution was $2 \%$ for the $\mathrm{Au} / \mathrm{La}: \mathrm{CuO} / \mathrm{n}-\mathrm{Si}$ diodes obtained by doping $2 \%, 5 \%$ and $10 \%$ $\mathrm{La}$ to $\mathrm{CuO}$. Based on these, we can state that doping changes the barrier height of the diode and that the highest and optimum barrier height is achieved with $1 \%$ initial $\mathrm{Cr}$ doping to $\mathrm{CuO}$ in our work. The $\mathrm{I}-\mathrm{V}$ graphs shown in Figure 5 deviate from linearity having relatively large forward biases associated with effects of series resistance. The diodes' series resistance can be investigated using Norde's method [62]. This includes a modified Norde function, and the function $\mathrm{F}(\mathrm{V})$ is expressed as:

$F(V)=\frac{V}{\gamma}+\frac{k T}{q} \ln \left(\frac{I(V)}{A^{*} A T^{2}}\right)$

Where $\gamma$ is a dimensionless arbitrary integer larger than idealty factor $\mathrm{n}$ and $I(V)$ is the diode's current in region of forward bias.

Figure 6 shows the $\mathrm{Cr}: \mathrm{CuO} / \mathrm{p}-\mathrm{Si}$ diodes' $\mathrm{F}(\mathrm{V})-\mathrm{V}$ graph for a few different concentrations of Cr doping. According to the Norde's method, the values of barrier height $\phi_{b}$ and series resistance $R_{s}$ are expressed by the equations below:

$\phi_{b}=F\left(V_{0}\right)+\frac{V_{0}}{\gamma}-\frac{k T}{q}$ 
$R_{S}=\frac{k T(\gamma-n)}{I_{0}}$

where $F\left(V_{0}\right)$ is the $\mathrm{F}(\mathrm{V})$ 's minimum point, $V_{0}$ and $I_{0}$ are voltage and current corresponding to this point, respectively. $\phi_{b}$ and $R_{s}$ values calculated by Norde's method are given in Table 1 . From the results, diode of $2 \%$ $\mathrm{Cr}: \mathrm{CuO} / \mathrm{p}-\mathrm{Si}$ exhibited the largest series resistance with $3,674 \mathrm{k} \Omega$, while diode of $1 \% \mathrm{Cr}: \mathrm{CuO} / \mathrm{p}-\mathrm{Si}$ showed the smallest series resistance. The obtained $\phi_{b}$ values from the experimental I-V data and calculated from the Norde's expression have similar variation inclination but marginally different. This difference is generally associated with barrier inhomogeneity and the non-linear behavior of diode [57,59].

To evaluate the $\mathrm{Cr}$ doping effect on the $\mathrm{CuO}$ based diodes' photoelectric properties, the diodes' I-V measurements in the dark and under light were taken and their plots are shown in figure 7 (a-d).

As can be seen from figure7 (a-d), the currents of all diodes under illumination are higher than currents in dark. However, when compared with the most of other diodes, the high light sensitivity was realized in the diode with $1 \% \mathrm{Cr}$ doping. Overall, illumination does not significantly change the forward bias currents whereas the reverse bias current changed significantly with illumination. Higher energy photons compared with the materials' optical band gap energies that make up the diode provide electron-hole pairs. Since these photo-generated carriers contribute more to the current carriers in the reverse bias region, a significant increase in current occurs in this region. Thus, the diodes produced exhibit the typical photosensitive property. Table 3 demonstrates the ratio of diodes' dark and illuminated reverse bias currents (at $-2 \mathrm{~V})$, open circuit voltage $\left(V_{O C}\right)$ and short circuit current $\left(I_{S C}\right)$.

For Schottky heterojunction diodes, measurements of capacitance are an important non-destructive technique to obtain information on constant charge concentration and barrier height. Figure 8 illustrates the $\% 1 \mathrm{Cr}: \mathrm{CuO} / \mathrm{p}-\mathrm{Si}$ heterojunctions' C-V measurements at different frequencies $(10 \mathrm{kHz}-1 \mathrm{Mhz})$ at $300 \mathrm{~K}$ in dark.

The capacitance values of the $\% 1 \mathrm{Cr}: \mathrm{CuO} / \mathrm{p}-\mathrm{Si}$ diode decrease with increasing frequency as given in Figure 8 . In general, the reverse bias voltage and frequency strongly effects the capacitance measurement in the Schottky diode. The capacitance's dependence on voltage and frequency is due to certain properties of the heterojunction, such as interface states, pollution level, series resistance as well as layer interface between $\mathrm{Cr}: \mathrm{CuO}$ and p-Si [63]. The capacitance's higher values at low frequencies may be associated with the interface states' continuous distribution and depletion capacitance of the diode [64]. On the other hand, charge carriers of high frequencies in the interface cannot contribute to the capacitance as they cannot track the signal of alternating current. As a result, the diode's capacitance value has a tendency to be the same while the frequency rises [65]. The a diode's depletion region capacitance is expressed as [66]:

$\frac{1}{C^{2}}=\frac{2\left(V_{b i}+V\right)}{q \varepsilon_{S} A^{2} N_{a}}$

where $\mathrm{A}$ is the area of diode, $\mathrm{V}$ is the voltage of reverse bias, $V_{b i}$ is the diffusion potential at zero bias and obtained from the $\mathrm{C}^{-2}-\mathrm{V}$ plot's extrapolation to the axis of $\mathrm{V}$, where $\varepsilon_{S}$ is the the semiconductor's (11.8 $\varepsilon_{0}$ for $\mathrm{p}$-Si) dielectric constant, $N_{a}$ is the p-type semiconductor's acceptor concentration.

Figure 9 demonstrates the $\mathrm{C}^{2}-\mathrm{V}$ and $\mathrm{C}-\mathrm{V}$ graphs of a $1 \% \mathrm{Cr}: \mathrm{CuO} / \mathrm{p}-\mathrm{Si}$ heterojunction diode at $1 \mathrm{Mhz}$ and temperature of $300 \mathrm{~K}$. The values of $V_{b i}$ and $N_{a}$ were found to be $0.59 \mathrm{eV}$ and $3.618 \times 10^{16} \mathrm{~cm}^{-3}$, respectively. The height of barrier could be determined employing the $\mathrm{C}-\mathrm{V}$ data by expression below:

$\phi_{b(C-V)}=V_{b i}+\frac{k T}{q} \ln \left(\frac{N_{v}}{N_{a}}\right)$

Where $N_{v}$ is the valance band states' effective density for $\mathrm{p}-\mathrm{Si}\left(N_{v}=3.2 \times 10^{19} \mathrm{~cm}^{-3}\right)$ [7]. The $1 \% \mathrm{Cr}: \mathrm{CuO}$ diode's barrier height was calculated as $0.765 \mathrm{eV}$ from the measurement of $\mathrm{C}-\mathrm{V}$. The diode's barrier height values attained from the I-V and C-V measurements are close. However, the values acquired by both methods are slightly different. This can also be described by the I-V and C-V measurements' different nature and the presence of semiconductor's interfacial layer as well as trap states [67,68]. 


\section{Conclusion}

In summary, $\mathrm{Cr}$ doped $\mathrm{CuO}$ thin films were grown on $\mathrm{SLG}$ substrate and $\mathrm{CuO} / \mathrm{p}-\mathrm{Si}$ and $\mathrm{Cr}: \mathrm{CuO} / \mathrm{p}-\mathrm{Si}$ structures were produced by depositing thin films on p-type $\mathrm{Si}$ wafers using method of spin coating and annealed at $500{ }^{\circ} \mathrm{C}$ for $1 \mathrm{~h}$ in air condition. The $\mathrm{Cr}$ doping effect on structural, optical, morphological and electrical properties of these films was comprehensively explored. The $\mathrm{CuO}$ films conjunction with $\mathrm{Cr}$ doping were monoclinic polycrystalline structure and with two main peaks (002) and (111) with $\mathrm{d}_{\mathrm{hkl}}$ about $2.52 \AA$ and $2.32 \AA$, respectively. The obtained thin film's XRD parameters including crystallite size, dislocation density and strain is slightly changed with increasing $\mathrm{Cr}$ concentration. The thin film's transmittance value was increased in the visible range as compared to undoped $\mathrm{CuO}$ thin film. The band gap energy was determined to be between 1.67 and $2.03 \mathrm{eV}$ with increasing $\mathrm{Cr}$ concentration. The energy band gap was radically increased with an increase of $\mathrm{Cr}$ concentration in $\mathrm{CuO}$. Additionally, $\mathrm{CuO} / \mathrm{p}-\mathrm{Si}$ and $\mathrm{Cr}: \mathrm{CuO} / \mathrm{p}$-Si structures were obtained by depositing thin films on p-type $\mathrm{Si}$ wafers via method of spin coating. The devices' electrical properties were analyzed in details using $I-V$ measurement in the dark and under illumination employing a solar simulator. $C-V$ measurements were carried out in the dark with a frequency range of 1 to $500 \mathrm{~Hz}$. The results reveals that Cr doping significantly altered the devices' electrical and photoelectrical parameters. The highest height of barrier, largest $V_{O C}$ and $I_{S C}$ were determined to be in $3 \% \mathrm{Cr}$ doped $\mathrm{CuO}$ thin films. Moreover, the structures formed using 3\% $\mathrm{Cr}$-doped $\mathrm{CuO}$ films exhibited the smallest ideality factor and series resistance. Thus, the obtained thin films parameters could be employed for photovoltaic devices on the future studies.

\section{References}

[1] B. J. Hansen, N. Kouklin, G. Lu, I.-K. Lin, J. Chen, and X. Zhang, J. Phys. Chem. C 114, 2440 (2010).

[2] F. Bayansal, S. Kahraman, G. Çankaya, H. Çetinkara, H. Güder, and H. Çakmak, J. Alloys Compd. 509, 2094 (2011).

[3] M. Rashad, M. Rüsing, G. Berth, K. Lischka, and A. Pawlis, J. Nanomater. 2013, 82 (2013).

[4] A. A. Ansari, M. Alhoshan, M. Alsalhi, and A. Aldwayyan, Biosensors, 302 (2010).

[5] T. Viet Pham, M. Rao, P. Andreasson, Y. Peng, J. Wang, and K. Jinesh, Appl. Phys. Lett. 102, 032101 (2013).

[6] M. Heinemann, B. Eifert, and C. Heiliger, Phys. Rev. B Condens. Matter 87, 115111 (2013).

[7] N. Serin, T. Serin, Ş. Horzum, and Y. Çelik, Semicond Sci Technol 20, 398 (2005).

[8] S. Mridha and D. Basak, Semicond Sci Technol 21, 928 (2006).

[9] T. Ishihara, M. Higuchi, T. Takagi, M. Ito, H. Nishiguchi, and Y. Takita, J. Mater. Chem. 8, 2037 (1998).

[10] B. S. Kang et al., Adv. Mater 20, 3066 (2008).

[11] S. K. Kumar, S. Suresh, S. Murugesan, and S. P. Raj, Sol Energy 94, 299 (2013).

[12] V. Ramya, K. Neyvasagam, R. Chandramohan, S. Valanarasu, and A. M. F. Benial, J. Mater. Sci.: Mater. Electron 26, 8489 (2015).

[13] Y. S. Chaudhary, S. A. Khan, C. Tripathi, R. Shrivastav, V. R. Satsangi, and S. Dass, Nucl Instrum Methods Phys Res B. 244, 128 (2006).

[14] L.-C. Chen, C.-C. Chen, K.-C. Liang, S. H. Chang, Z.-L. Tseng, S.-C. Yeh, C.-T. Chen, W.-T. Wu, and C.-G. Wu, Nanoscale Res. Lett. 11, 402 (2016).

[15] D. P. Dubal, G. S. Gund, R. Holze, H. S. Jadhav, C. D. Lokhande, and C.-J. Park, Dalton Trans. 42, 6459 (2013).

[16] K. Mageshwari and R. Sathyamoorthy, Mater Sci Semicond Process. 16, 337 (2013).

[17] N. Mukherjee, B. Show, S. K. Maji, U. Madhu, S. K. Bhar, B. C. Mitra, G. G. Khan, and A. Mondal, Mater. Lett. 65, 3248 (2011).

[18] S. C. Ray, Sol. Energy Mater Sol. Cells. 68, 307 (2001).

[19] N. A. M. Shanid and M. A. Khadar, Thin Solid Films 516, 6245 (2008).

[20] M. F. Al-Kuhaili, Vacuum 82, 623 (2008).

[21] S. H. Wee, P.-S. Huang, J.-K. Lee, and A. Goyal, Sci. Rep. 5, 16272 (2015).

[22] V. Figueiredo, E. Elangovan, G. Gonçalves, P. Barquinha, L. Pereira, N. Franco, E. Alves, R. Martins, and E. Fortunato, Appl. Surf. Sci. 254, 3949 (2008).

[23] H. S. Kim, J. W. Lim, S. J. Yun, M. A. Park, S. Y. Park, S. E. Lee, and H. C. Lee, Jpn. J. Appl. Phys. 52, 10MB17 (2013).

[24] P. Cova and A. Singh, Solid State Electron. Lett. 33, 11 (1990).

[25] Ş. Karataş and Ş. Altindal, Solid State Electron. Lett. 49, 1052 (2005).

[26] S. Bhuvaneshwari and N. Gopalakrishnan, J. Alloys Compd. 654, 202 (2016).

[27] K. M. Kim, H. M. Jeong, H. R. Kim, K. I. Choi, H. J. Kim, and J. H. Lee, Sensors (Basel) 12, 8013 (2012).

[28] B. Gu and S. Maekawa, AIP Adv. 7, 055805 (2017). 
[29] S. G. Yang, A. B. Pakhomov, S. T. Hung, and C. Y. Wong, Appl. Phys. Lett. 81, 2418 (2002).

[30] S. Yilmaz, M. Parlak, S. Özcan, M. Altunba, E. McGlynn, and E. Bacaksiz, Appl. Surf. Sci. 257, 9293 (2011).

[31] C. Guillén and J. Herrero, J. Alloys Compd. 737, 718 (2018).

[32] P. Samarasekara, P. Karunarathna, H. Weeramuni, and C. Fernando, Mater. Res. Express 5, 066418 (2018).

[33] M. Shaban, K. Abdelkarem, and A. M. El Sayed, Phase Transit. 92, 347 (2019).

[34] S. Pat, R. Mohammadigharehbagh, C. Musaoğlu, S. Özen, and Ş. Korkmaz, Optik (Stuttg.) 180, 350 (2019).

[35] S. Baturay, A. Tombak, D. Kaya, Y. S. Ocak, M. Tokus, M. Aydemir, and T. Kilicoglu, J Solgel Sci Technol 78, 422 (2016).

[36] J. Shaikh, R. Pawar, R. Devan, Y. Ma, P. Salvi, S. Kolekar, and P. Patil, Electrochim. Acta 56, 2127 (2011)

[37] D. P. Joseph, C. Venkateswaran, S. Sambasivam, and B. C. Choi, J Korean Phys Soc. 61, 449 (2012).

[38] A. Yildiz, S. Horzum, N. Serin, and T. Serin, Appl. Surf. Sci. 318, 105 (2014).

[39] Y. Wang, T. Jiang, D. Meng, D. Wang, and M. Yu, Appl. Surf. Sci. 355, 191 (2015).

[40] J. Tamaki, K. Shimanoe, Y. Yamada, Y. Yamamoto, N. Miura, and N. Yamazoe, Sens. Actuators B Chem. 49, 121 (1998).

[41] H. Y. Bae and G. M. Choi, Sens. Actuators B Chem. 55, 47 (1999).

[42] Y. S. Chaudhary, A. Agrawal, R. Shrivastav, V. R. Satsangi, and S. Dass, Int. J. Hydrog. Energy. 29, 131 (2004)

[43] J. Morales, L. Sanchez, F. Martin, J. Ramos-Barrado, and M. Sanchez, Thin Solid Films 474, 133 (2005).

[44] L. Obulapathi, A. G. Kumar, T. S. Sarmash, and T. S. Rao, Int. j. nanotechnol. appl. 4, 29 (2014).

[45] B. D. Cullity, Elements of X-ray Diffraction (Addison-Wesley Publishing, 1956).

[46] G. Durai, P. Kuppusami, S. Arulmani, S. Anandan, S. Khadeer Pasha, and S. Kheawhom, Int. J. Energy Res. (2021).

[47] S. Manjunatha, R. H. Krishna, T. Thomas, B. Panigrahi, and M. Dharmaprakash, Mater. Res. Bull. 98, 139 (2018).

[48] S. Dolai, R. Dey, S. Das, S. Hussain, R. Bhar, and A. Pal, J. Alloys Compd. 724, 456 (2017).

[49] A. Menazea and A. M. Mostafa, J. Environ. Chem. Eng. 8, 104104 (2020).

[50] J. Tauc, Amorphous and liquid semiconductors (Springer Science \& Business Media, 2012).

[51] Y. Gülen, F. Bayansal, B. Şahin, H. A. Çetinkara, and H. S. Güder, Ceram. Int. 39, 6475 (2013).

[52] M. Sajid, M. Imran, Salahuddin, and J. Iqbal, Appl. Phys. A 124, 768 (2018).

[53] M. R. Das and P. Mitra, J Solgel Sci Technol 87, 59 (2018).

[54] G. Y. Naser, W. N. Raja, A. S. Faris, Z. J. Rahem, M. A. Salih, and A. H. Ahmed, Energy Procedia 36, 42 (2013).

[55] C. COŞKUN, H. GÜNEY, E. Gür, and S. TÜZEMEN, Turk. J. Phys. 33, 49 (2009).

[56] Y. Caglar, M. Caglar, S. Ilican, and F. Yakuphanoglu, Microelectron. Eng. 86, 2072 (2009).

[57] İ. Y. Erdoğan and Ö. Güllü, J. Alloys Compd. 492, 378 (2010).

[58] R. Tung, Phys. Rev. B Condens. Matter. 45, 13509 (1992).

[59] S. Ruzgar, Y. Caglar, O. Polat, D. Sobola, and M. Caglar, Surf. Interfaces. 21, 100750 (2020).

[60] Ç. Bilkan, S. Zeyrek, S. San, and Ş. Altındal, Mater Sci Semicond Process. 32, 137 (2015).

[61] R. Singh, L. Yadav, and T. Shweta, Thin Solid Films 685, 195 (2019).

[62] H. Norde, J. Appl. Phys. 50, 5052 (1979).

[63] Ö. Güllü, S. Asubay, Ş. Aydoğan, and A. Türüt, Physica E Low Dimens. Syst. Nanostruct. 42, 1411 (2010).

[64] H. Aydin, A. Tataroğlu, A. A. Al-Ghamdi, F. Yakuphanoglu, F. El-Tantawy, and W. Farooq, J. Alloys Compd. 625, 18 (2015).

[65] S. Baturay, Y. S. Ocak, and D. Kaya, J. Alloys Compd. 645, 29 (2015).

[66] E. H. Rhoderick, IEE Proceedings I-Solid-State and Electron Devices 129, 1 (1982).

[67] S. Ruzgar and S. A. Pehlivanoglu, Superlattices Microstruct. 145, 106636 (2020).

[68] Ö. Güllü, T. Kilicoglu, and A. Türüt, J Phys Chem Solids. 71, 351 (2010). 


\section{Statements \& Declarations}

\section{Funding}

The authors declare that no funds, grants, or other support were received during the preparation of this manuscript.

\section{Competing Interests}

The authors have no relevant financial or non-financial interests to disclose.

\section{Author Contributions}

All authors contributed to the study conception and design. Material preparation, data collection and analysis were performed by Silan BATURAY, Ilhan CANDAN and Cihat OZAYDIN. The first draft of the manuscript was written by Silan BATURAY and all authors commented on previous versions of the manuscript. All authors read and approved the final manuscript.

\section{Research Data Policy and Data Availability Statements}

Data will be made available on reasonable request.

\section{Compliance with Ethical Standards}

This article does not contain any studies involving animals performed by any of the authors. This article does not contain any studies involving human participants performed by any of the authors.

\section{Highlights}

- Undoped and $\mathrm{Cr}$ doped $\mathrm{CuO}$ thin films were deposited onto glass substrates and $\mathrm{p}$-Si semiconductor by spin coating method.

- The $\mathrm{Cr}: \mathrm{CuO} / \mathrm{p}-\mathrm{Si}$ heterojunctions were compared with undoped $\mathrm{CuO} / \mathrm{p}-\mathrm{Si}$ heterojunction.

- The $\mathrm{Cr}: \mathrm{CuO} / \mathrm{p}-\mathrm{Si}$ diodes generated by $1 \% \mathrm{Cr}$ doping using spin coating method had the highest light sensitivity compared with those of the other diodes.

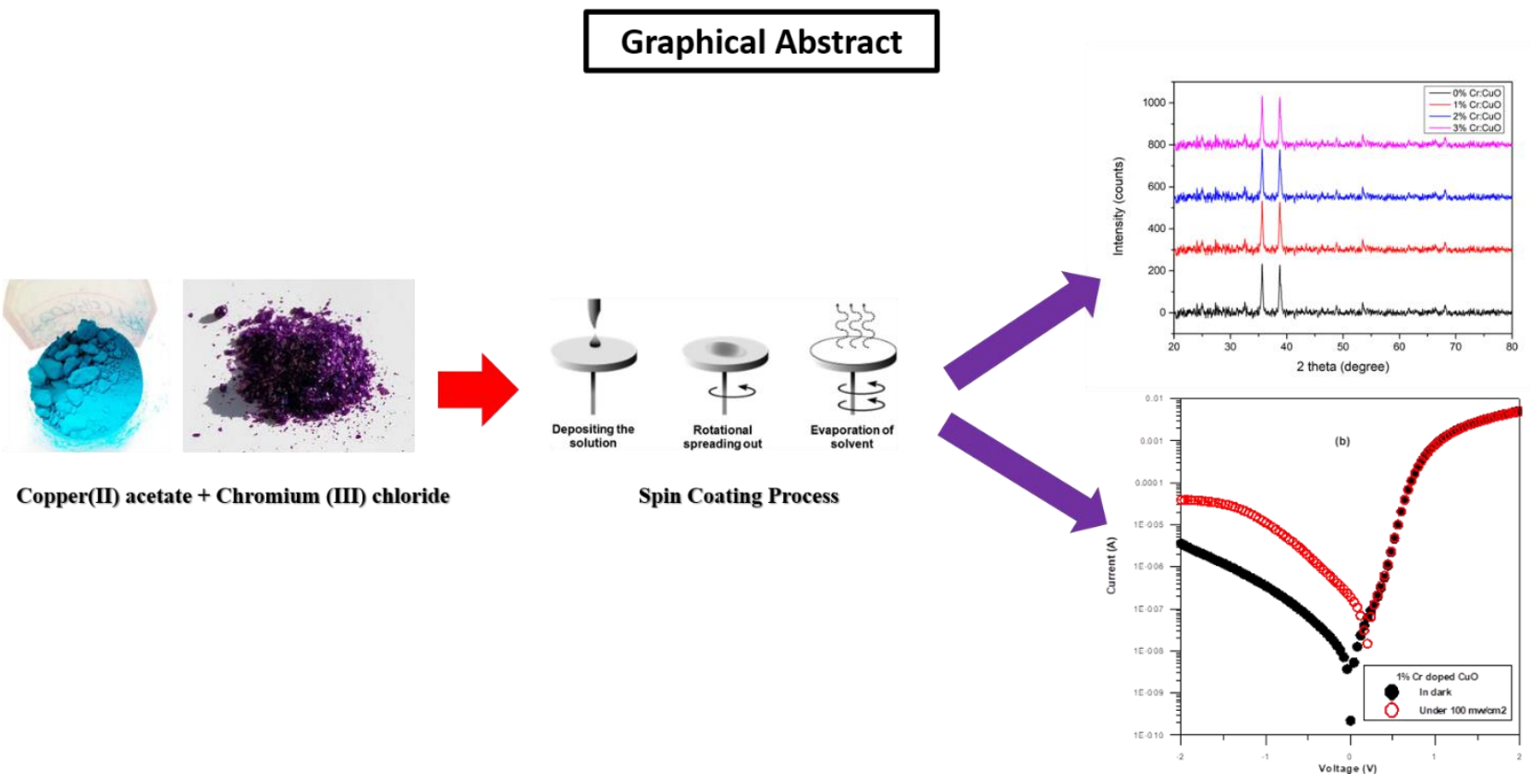

Fig. Graphical abstract. 


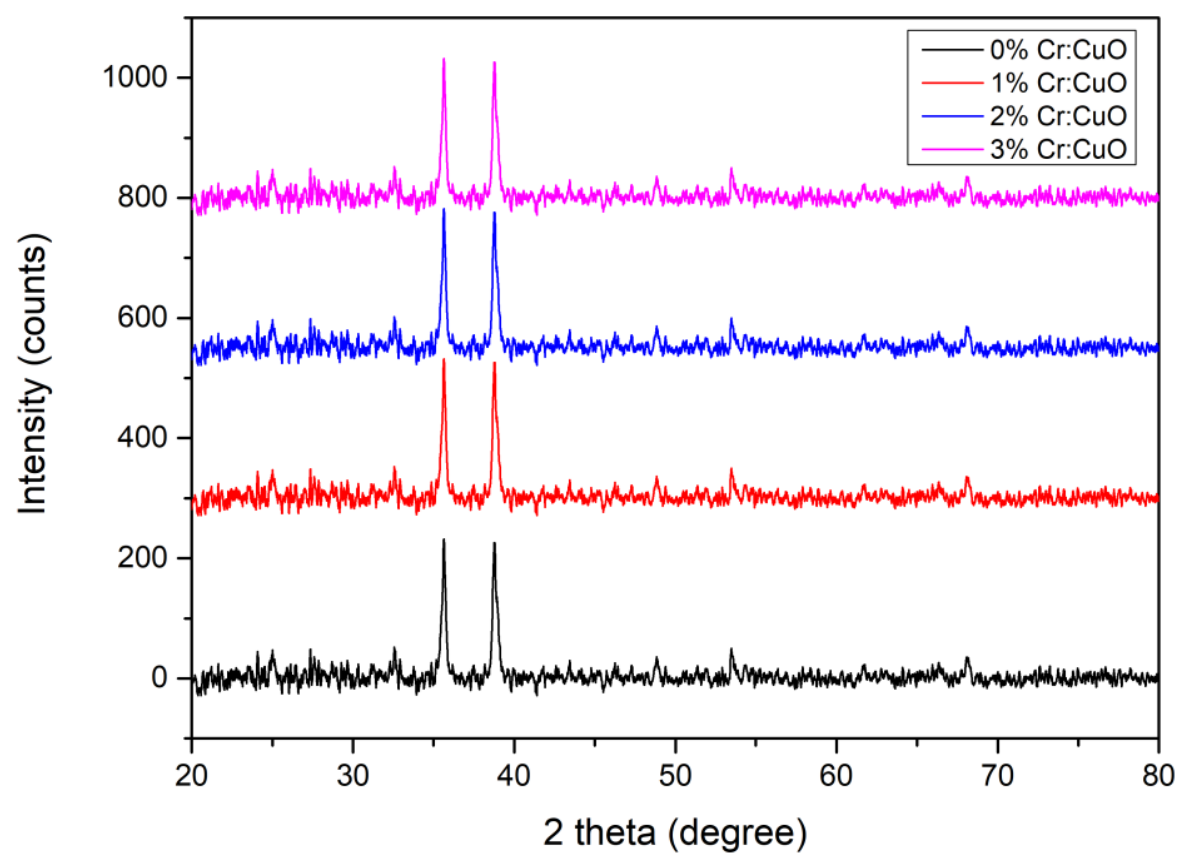

Fig. 1 XRD patterns $\mathrm{CuO}$ thin films with $\mathrm{Cr}$ doping.

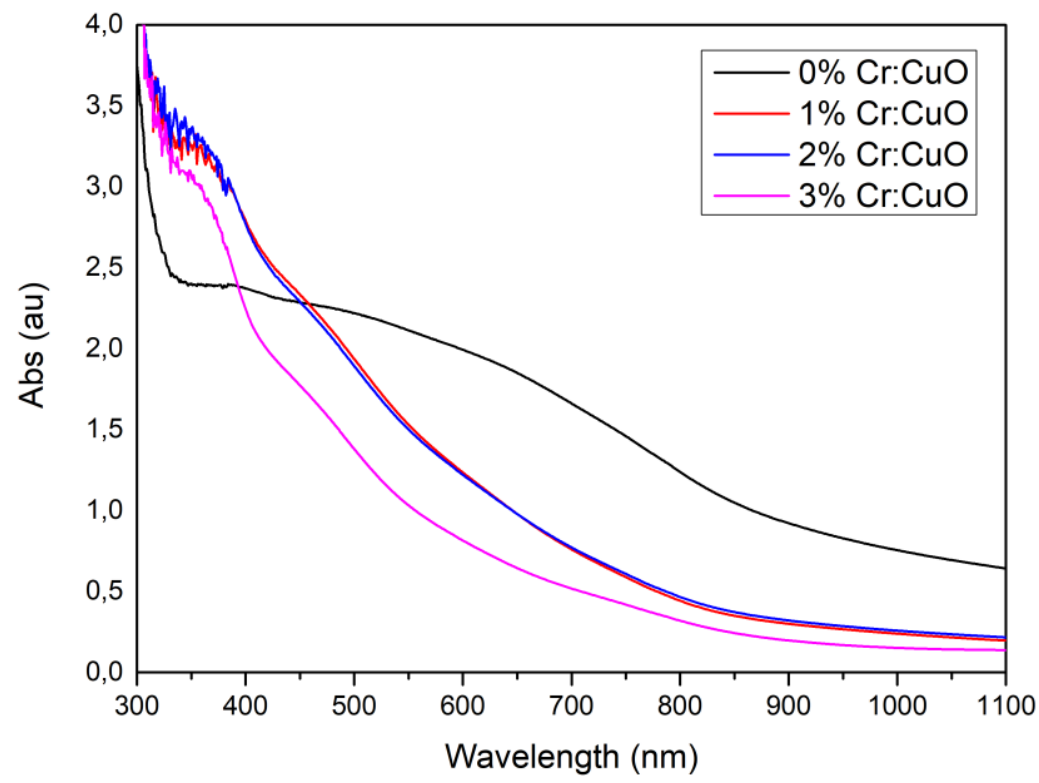

Fig. 2 Absorbance spectrum of $\mathrm{CuO}$ thin films for different $\mathrm{Cr}$ concentrations. 


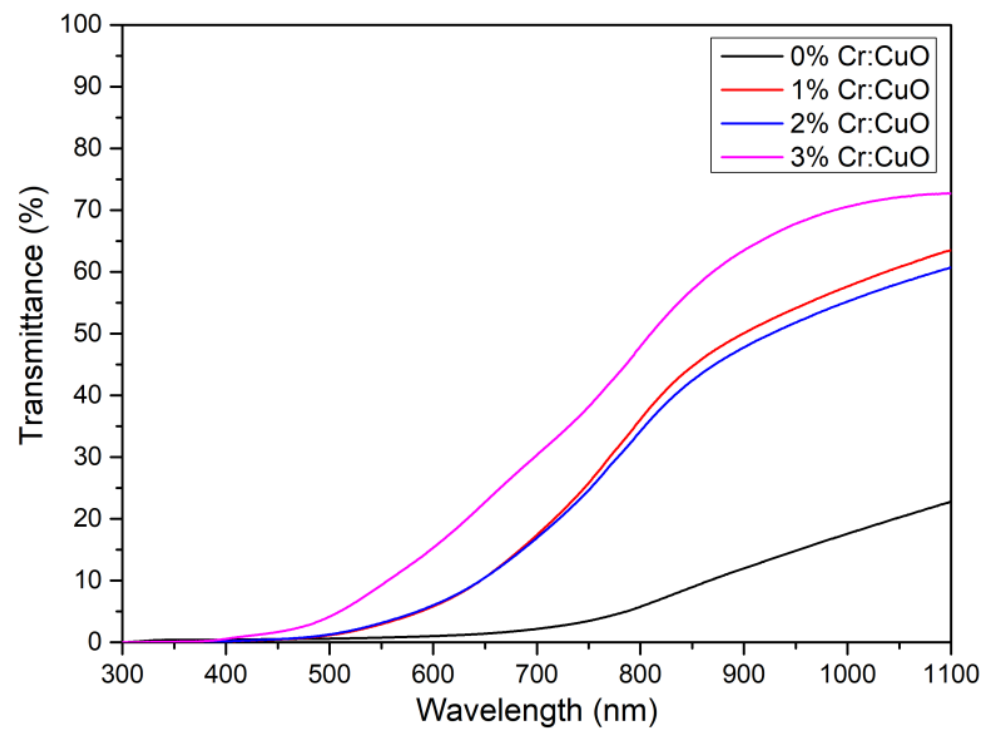

Fig. 3 Transmittance spectrum of $\mathrm{CuO}$ thin films for different $\mathrm{Cr}$ concentrations.
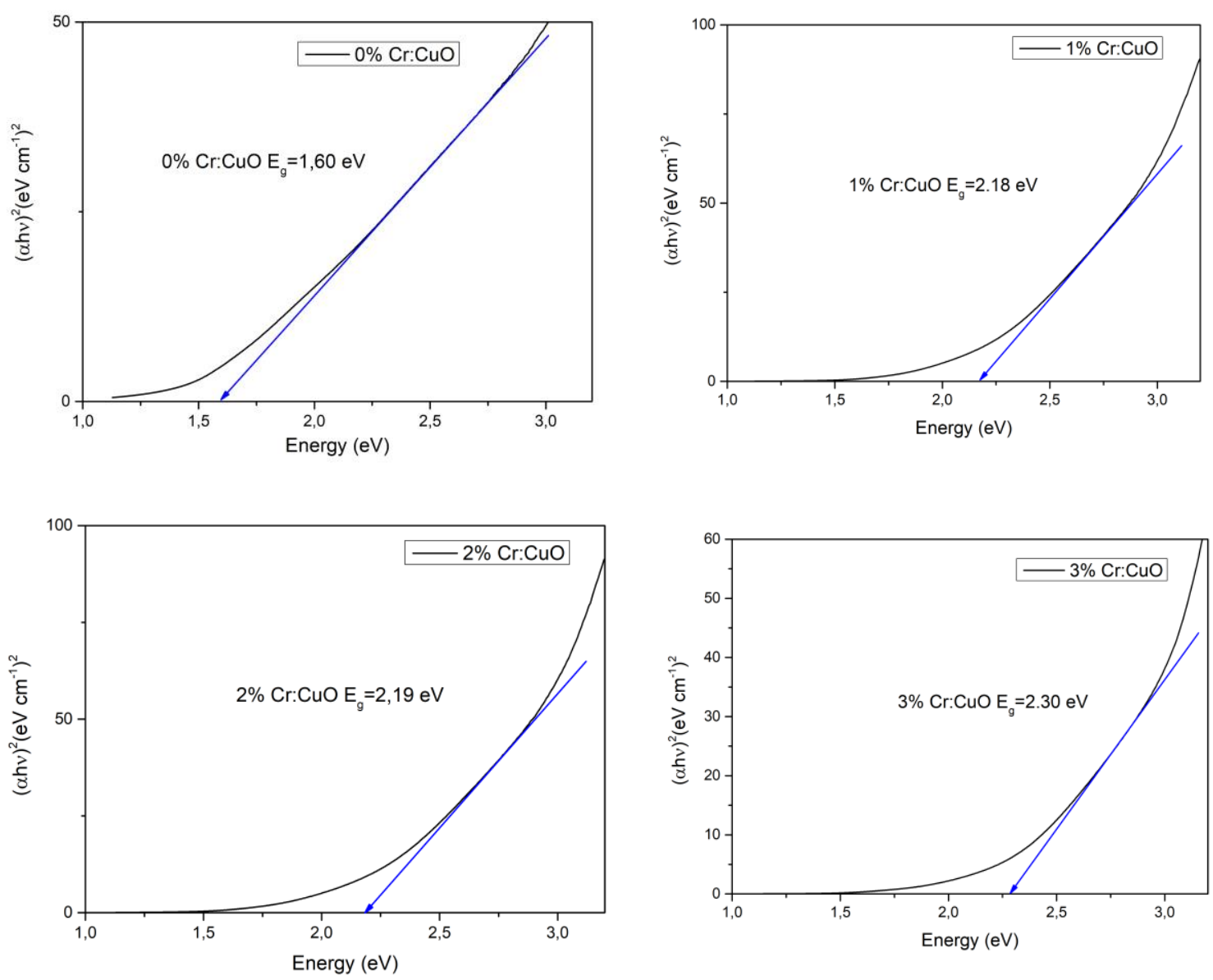
Fig. $4(\alpha h v)^{2}$ vs. $h v$ plot of $\mathrm{Cr}$ doped $\mathrm{CuO}$ thin film on sodalime glass substrate.

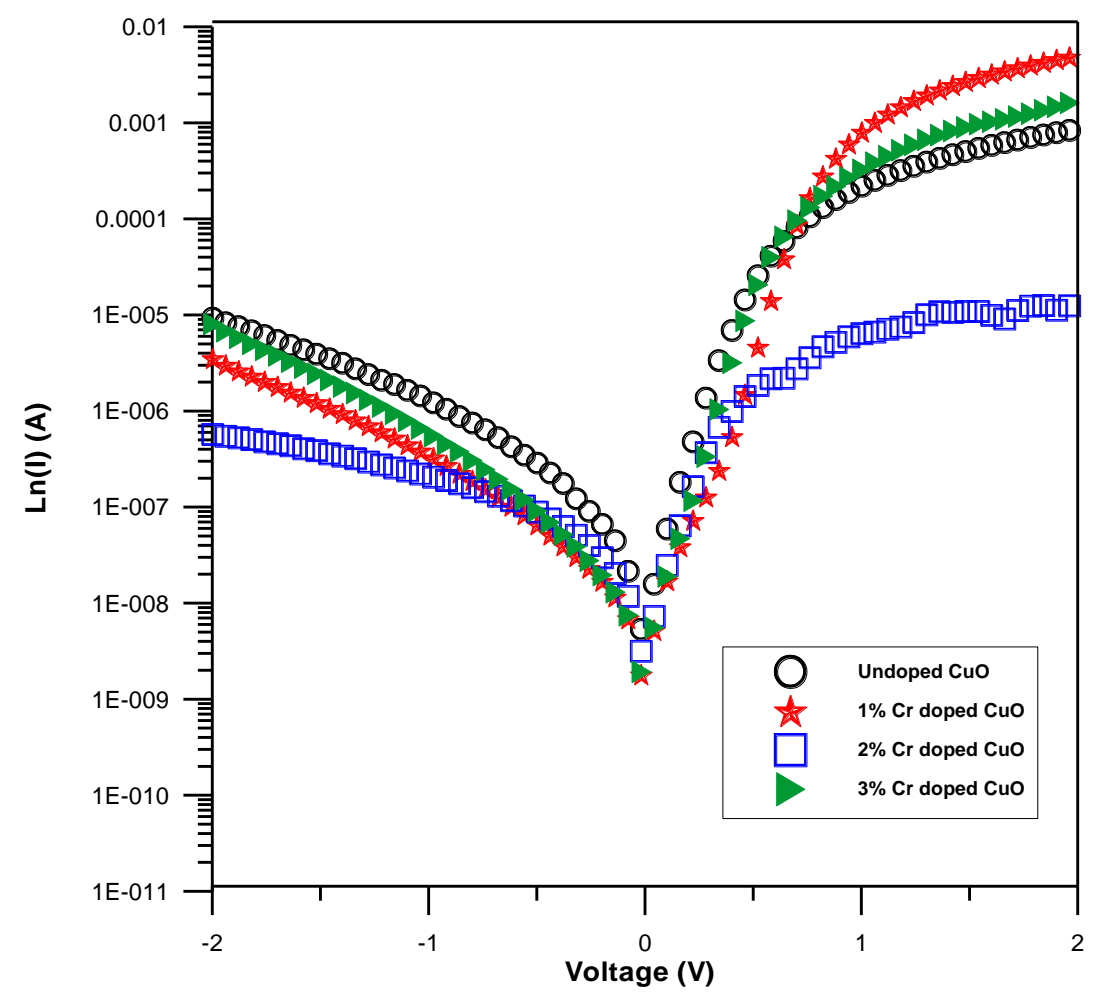

Fig 5. Semi-logarithmic I-V plots of the $\mathrm{Cr}: \mathrm{CuO}$ diodes in dark.

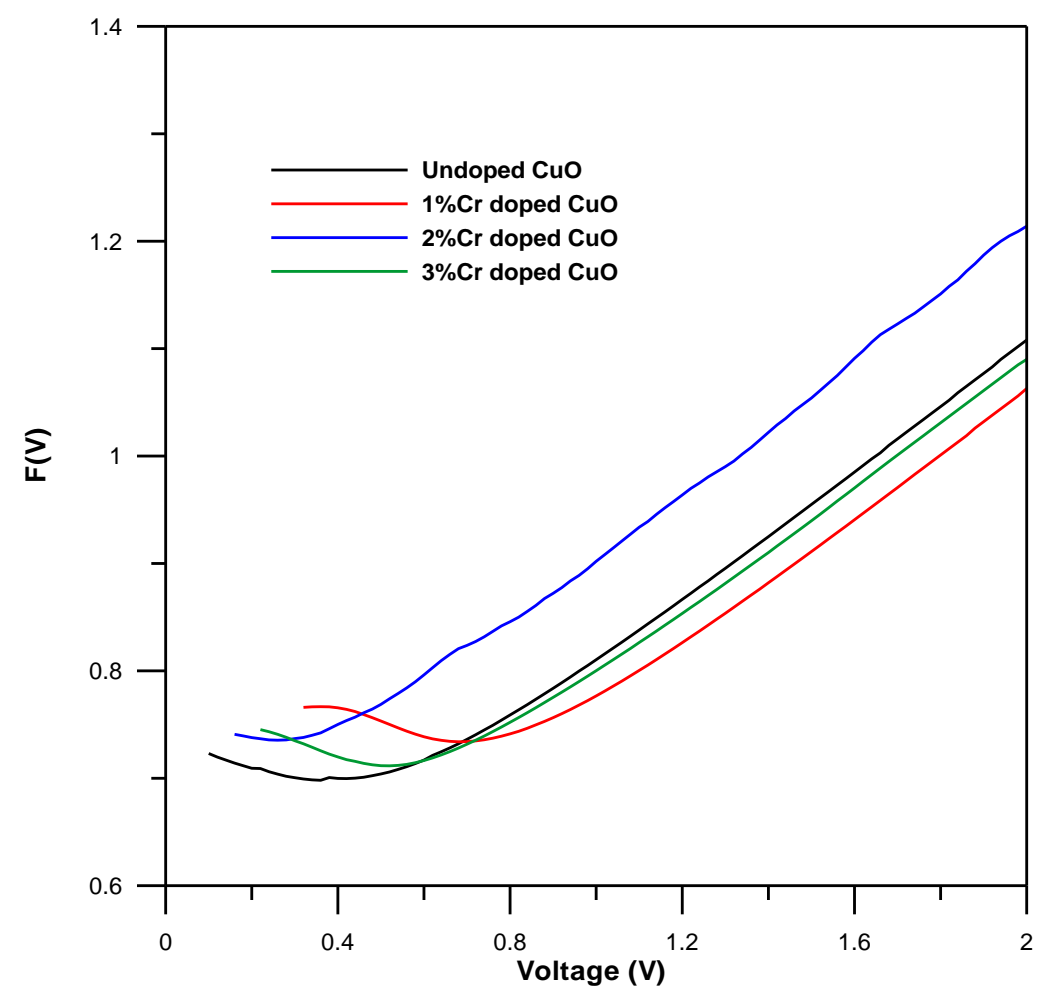

Fig. 6 Norde plots of the $\mathrm{CuO} / \mathrm{p}-\mathrm{Si}$ and $\mathrm{Cr}: \mathrm{CuO} / \mathrm{p}-\mathrm{Si}$ heterojunctions. 

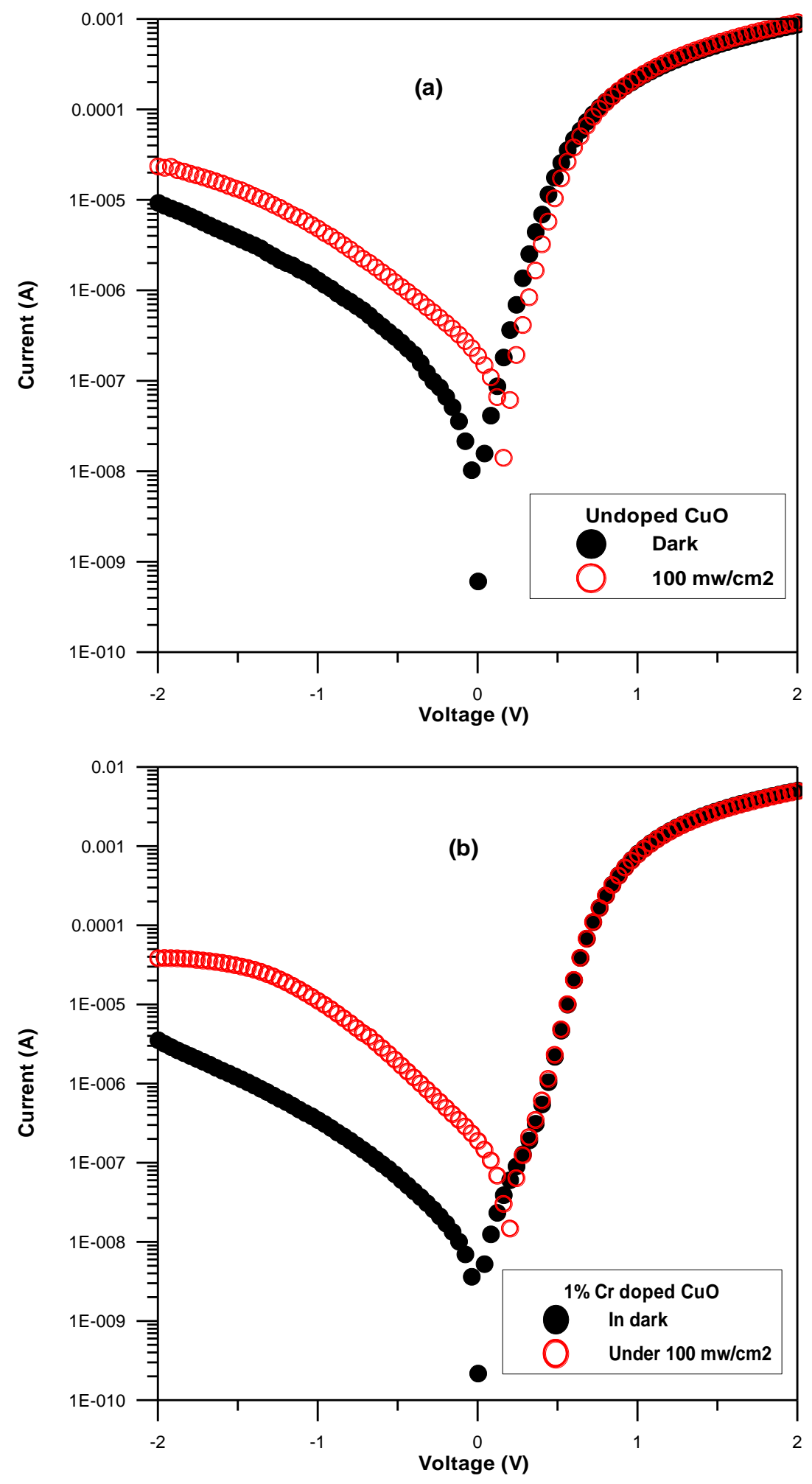

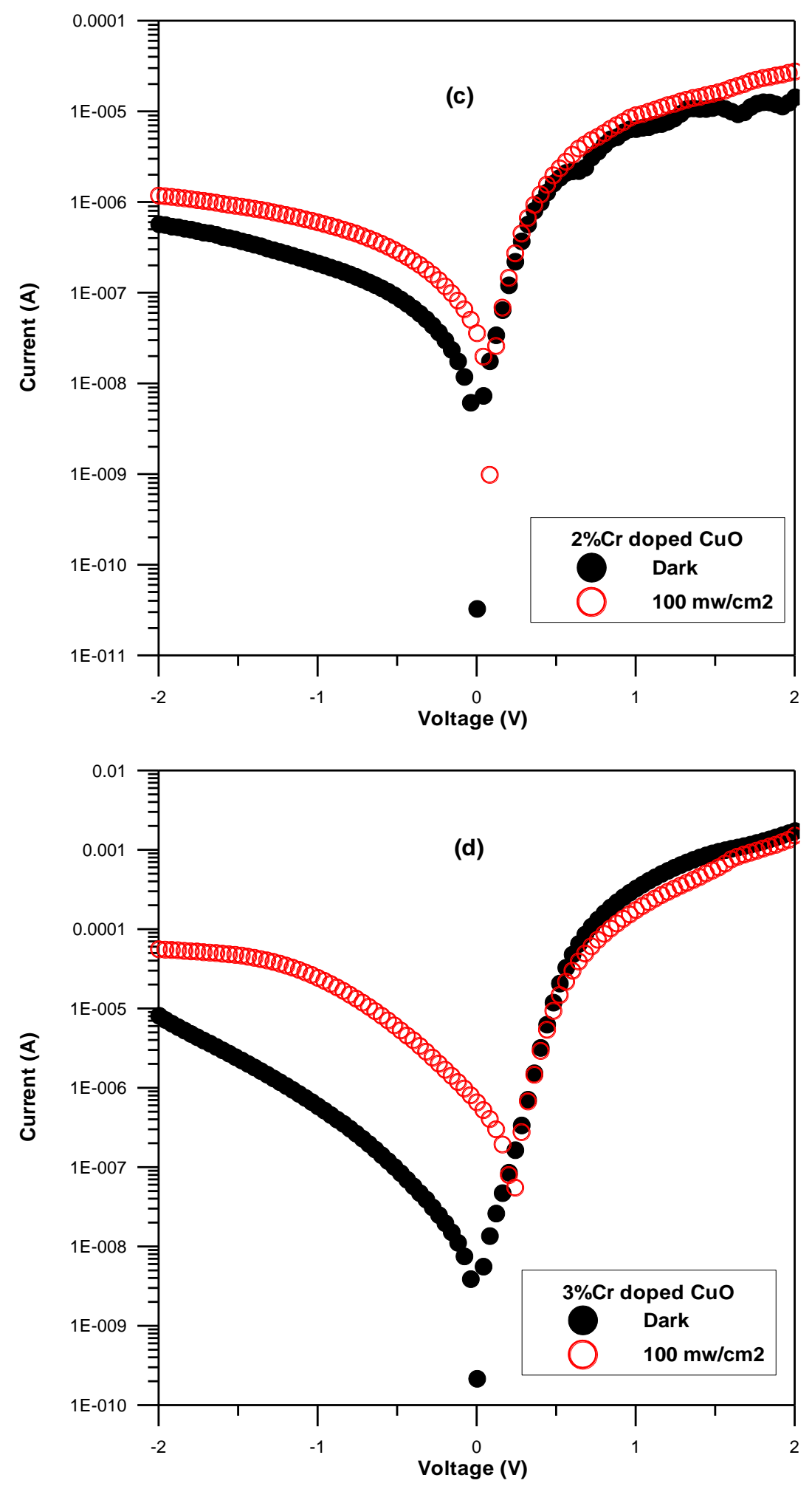

Fig. 7(a-d) $\ln \mathrm{I}-\mathrm{V}$ plots of the $\mathrm{CuO} / \mathrm{p}-\mathrm{Si}$ and $\mathrm{Cr}: \mathrm{CuO} / \mathrm{p}-\mathrm{Si}$ heterojunctions in the dark and under light $(100$ $\left.\mathrm{mW} / \mathrm{cm}^{2}\right)$. 


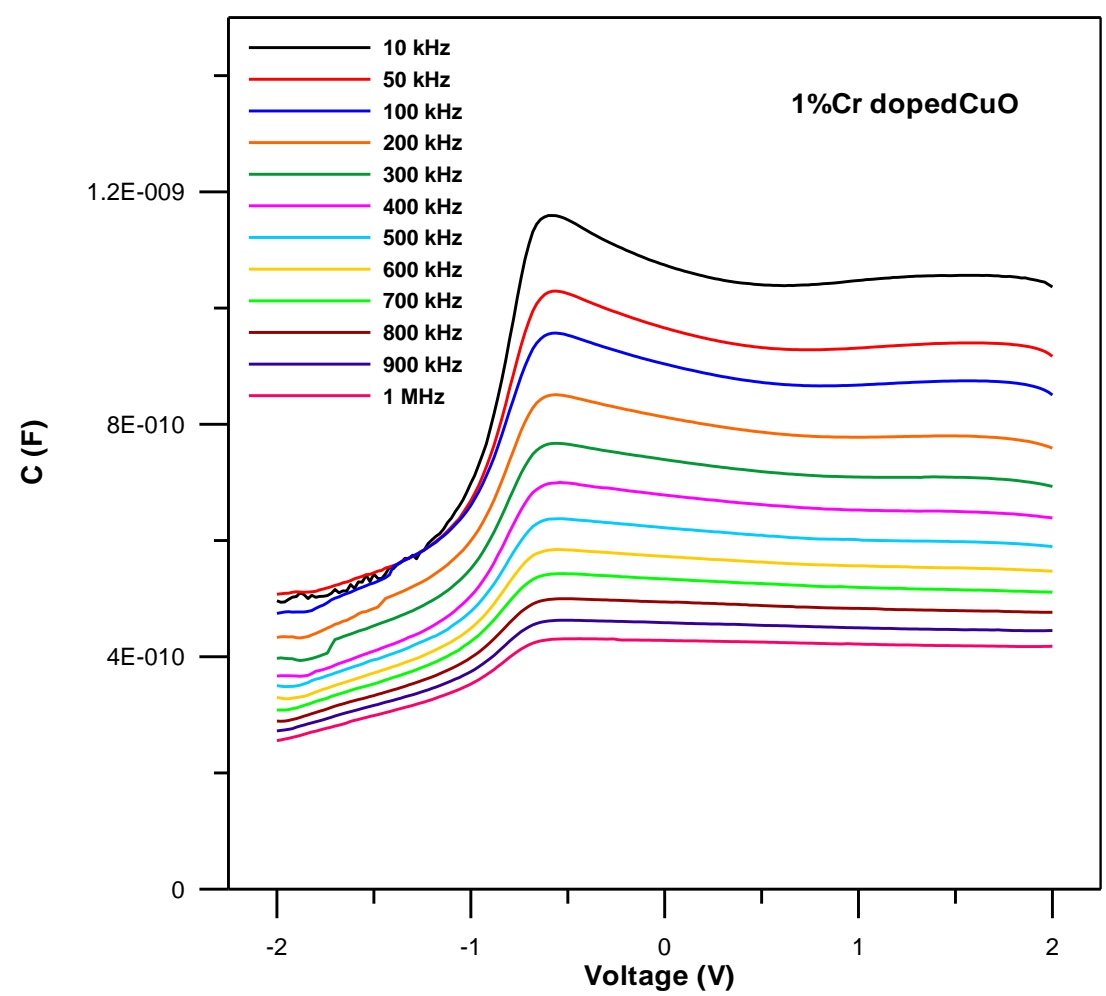

Fig. 8 The $\mathrm{C}-\mathrm{V}$ measurements of the $1 \% \mathrm{Cr}: \mathrm{CuO} / \mathrm{p}-\mathrm{Si}$ heterojunctions at different frequencies $(10 \mathrm{kHz}-1 \mathrm{Mhz})$

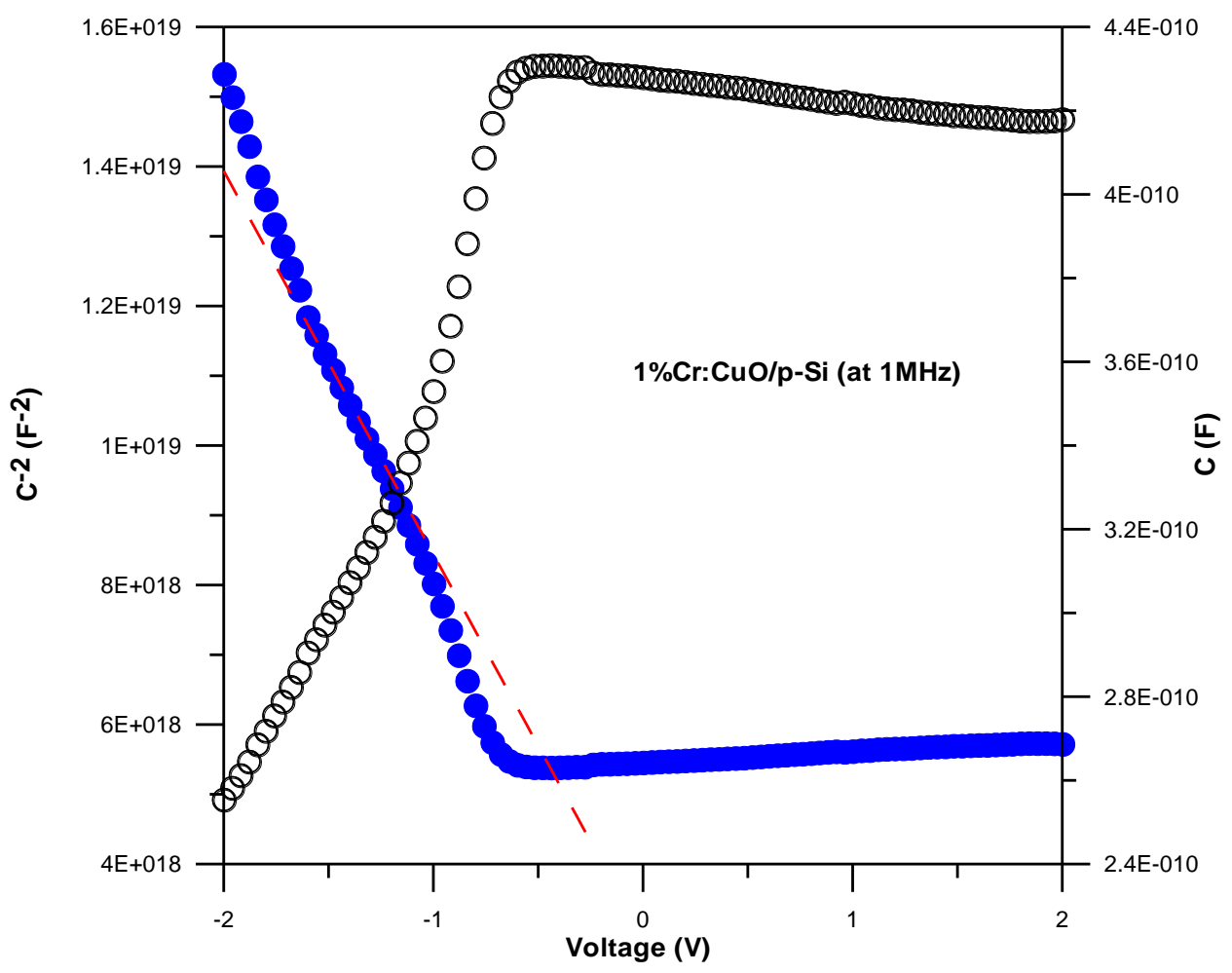

Fig. $9 \mathrm{C}^{2}-\mathrm{V}$ and $\mathrm{C}-\mathrm{V}$ plots of $1 \% \mathrm{Cr}: \mathrm{CuO} / \mathrm{p}-\mathrm{Si}$ heterojunctions at $1 \mathrm{MHz}$. 
Table 1. Crystallite size, dislocation density and strain value of the undoped and $\mathrm{Cr}$-doped $\mathrm{CuO}$ films obtained by XRD

\begin{tabular}{|c|c|c|c|c|c|c|c|}
\hline & $\begin{array}{l}\text { Theta } \\
\text { peaks }(\theta)\end{array}$ & $\begin{array}{l}\text { Grain } \\
\text { size }(\mathrm{nm})\end{array}$ & $\begin{array}{l}\text { d-spacing }\left(\mathrm{A}^{\circ}\right) \\
\text { (calculated) }\end{array}$ & $\begin{array}{l}\text { d-spacing }\left(\mathrm{A}^{\circ}\right) \\
\text { (standart) }\end{array}$ & Orientation & $\begin{array}{l}\text { Dislocation } \\
\text { density }\left(\times 10^{15} \mathrm{~m}^{-2}\right)\end{array}$ & strain \\
\hline \multirow[t]{2}{*}{ Undoped } & 35.63 & 27.35 & 2.52 & 2.520 & $(002)$ & 1.34 & 0.25 \\
\hline & 38.79 & 19.61 & 2.32 & 2.319 & (111) & 2.60 & 0.32 \\
\hline \multirow[t]{2}{*}{$1 \%$ Cr-doped } & 35.64 & 19.25 & 2.52 & 2.519 & $(002)$ & 2.70 & 0.35 \\
\hline & 38.77 & 26.20 & 2.32 & 2.323 & (111) & 1.46 & 0.24 \\
\hline \multirow[t]{2}{*}{$2 \%$ Cr-doped } & 35.64 & 25.73 & 2.52 & 2.521 & $(002)$ & 1.51 & 0.26 \\
\hline & 38.78 & 20.10 & 2.32 & 2.323 & (111) & 2.48 & 0.31 \\
\hline \multirow[t]{2}{*}{$3 \%$ Cr-doped } & 35.65 & 16.94 & 2.52 & 2.519 & $(002)$ & 3.49 & 0.40 \\
\hline & 38.77 & 15.31 & 2.32 & 2.323 & (111) & 4.27 & 0.41 \\
\hline
\end{tabular}

Table 2. The electrical parameters of $\mathrm{Cr}: \mathrm{CuO} / \mathrm{p}$-Si diodes with different doping ratios $(0 \%, 1 \%, 2 \%$ and $3 \%)$ at $300 \mathrm{~K}$ and dark conditions.

\begin{tabular}{lcccccc}
\hline Sample & $\boldsymbol{n}$ & $\begin{array}{c}\boldsymbol{\phi}_{\boldsymbol{b}}(\mathrm{I}-\mathrm{V}) \\
(\mathrm{eV})\end{array}$ & $\boldsymbol{I}_{\mathbf{0}}(\mathrm{A})$ & $\begin{array}{c}\boldsymbol{R} \boldsymbol{R}(\mathrm{for} \\
\mathbf{1 1 V})\end{array}$ & $\begin{array}{c}\boldsymbol{\phi}_{\boldsymbol{b}} \text { (Norde) } \\
(\mathrm{eV})\end{array}$ & $\begin{array}{c}\boldsymbol{R}_{\boldsymbol{s}}(\mathbf{k} \boldsymbol{\Omega}) \\
(\text { Norde) }\end{array}$ \\
\hline $\mathbf{0 \% C r : C u O / p - S i}$ & 2.28 & 0.73 & $1.16 \times 10^{-8}$ & 170.7 & 0.791 & 4.173 \\
$\mathbf{1 \% C r : C u O / p - S i}$ & 2.17 & 0.81 & $4.55 \times 10^{-10}$ & 2335.4 & 0.734 & 0.312 \\
$\mathbf{2 \% C r : C u O / p - S i}$ & 2.47 & 0.75 & $5.26 \times 10^{-9}$ & 30.4 & 0.803 & 36.74 \\
$\mathbf{3 \% C r : C u O / p - S i}$ & 2.14 & 0.77 & $2.22 \times 10^{-9}$ & 557.2 & 0.859 & 1.064 \\
\hline
\end{tabular}

Table 3 Photoelectrical parameters of $\mathrm{CuO} / \mathrm{p}-\mathrm{Si}$ and $\mathrm{Cr}: \mathrm{CuO} / \mathrm{p}-\mathrm{Si}$ diodes under illumination with $100 \mathrm{~mW} / \mathrm{cm}^{2}$ light

\begin{tabular}{|c|c|c|c|}
\hline Diode & $\begin{array}{c}\text { Photo sensitivity } \\
\text { ratio }\end{array}$ & $V_{o c}(\mathrm{mV})$ & $I_{s c}(\mu \mathrm{A})$ \\
\hline $\mathrm{CuO} / \mathrm{p}-\mathrm{Si}$ & 3.30 & 160 & 0.190 \\
\hline $1 \% \mathrm{Cr}$ doped cuO/p-Si & 33.74 & 180 & 0.191 \\
\hline $2 \% \mathrm{Cr}$ doped cuO/p-Si & 2.06 & 80 & 0.036 \\
\hline $3 \% \mathrm{Cr}$ doped cuO/p-Si & 27.82 & 220 & 0.663 \\
\hline
\end{tabular}

